\title{
Detection of Brucella spp. in artisan cheese commercialized in Parnaíba, Piauí state, Brazil
}

\author{
[Detecção de Brucella spp. em queijos artesanais comercializados em Parnaíba, Estado do Piauí, \\ Brasil]
}

\section{"Artigo Científico/Scientific Article"}

\author{
Suely Santos Bezerra ${ }^{1, *}$, Pomy de Cássia Peixoto Kim $^{2}$, Francisco José de Seixas Santos ${ }^{3}$, \\ Karina Neoob de Carvalho Castro ${ }^{4}$, Nair Silva Cavalcanti Lira ${ }^{5}$, Emiko Shinozaki Mendes ${ }^{2}$
}

\author{
${ }^{1}$ Instituto Federal de Educação, Ciência e Tecnologia de Pernambuco (IFPE) Campus Recife, Recife-PE, Brasil. \\ ${ }^{2}$ Departamento de Medicina Veterinária, Universidade Federal Rural de Pernambuco (UFRPE), Recife-PE, Brasil. \\ ${ }^{3}$ Embrapa Meio-Norte, Parnaíba-PI, Brasil. \\ ${ }^{4}$ Embrapa Tabuleiros Costeiros, Aracaju-SE, Brasil. \\ ${ }^{5}$ Universidade Federal Rural de Pernambuco - Unidade Acadêmica de Garanhuns (UAG) Garanhuns-PE, Brasil. \\ *Autor para correspondência/Corresponding author: E-mail: susbezerra @gmail.com
}

\begin{abstract}
The aim of this study was to detect Brucella spp. in artisanal cheese commercialized in Parnaíba city, Piauí state, Brazil. For this study, 30 samples of curd cheese $(500 \mathrm{~g})$ were randomly collected from different points in the commercialization process. In the laboratory, $25 \mathrm{~g}$ aliquots of the samples were suspended in Brucella broth; after this procedure, $10 \mu \mathrm{L}$ aliquots of this suspension were sown in Thayer Martin agar plates that were supplemented with $10 \%$ defibrinated sheep blood and VCNT antimicrobials. After inoculation, the samples were incubated at $37^{\circ} \mathrm{C}$ in microaerophilic conditions for 14 days. The suspected morphological colonies were identified and confirmed by polymerase chain reaction (PCR). From thirty samples of microbiologically analyzed cheeses, six samples (20\%) were confirmed by PCR as bacteria from the Brucella genus. The detection of Brucella spp. was confirmed in cheese commercialized in markets or a public square (3.33\%), bakery $(3.33 \%)$ and small market (13.33\%). Brucella spp. was detected in artisanal cheese commercialized in different points from Parnaíba city. Guidelines for the establishment of good practices for the production of artisanal cheese should be determined by the competent authorities. However, for the better control of human brucellosis it is necessary to control or eradicate bovine brucellosis in the herds.
\end{abstract}

Keywords: microbiology; food safety; dairy.

\begin{abstract}
Resumo
Objetivou-se com este estudo detectar Brucella spp. em queijo artesanal comercializado na cidade de Parnaíba, estado do Piaú, Brasil. Para este estudo, foram coletadas 30 amostras de queijo (500g) de diferentes pontos de comercialização, escolhidos de forma aleatória. No laboratório alíquotas de $25 \mathrm{~g}$ das amostras foram suspensas em caldo Brucella, após esse procedimento $10 \mu \mathrm{L}$ dessa suspensão, foi semeado em placas contendo ágar Thayer Martin suplementado com 10\% de sangue de carneiro desfibrinado e antimicrobiano VCNT. Após a inoculação as amostras foram incubadas a $37^{\circ} \mathrm{C}$ em microaerofilia por até 14 dias, as colônias morfologicamente suspeitas foram identificadas e confirmadas pela reação em cadeia da polimerase (PCR). Das 30 amostras de queijos analisadas microbiologicamente, seis (20\%) foram confirmadas por PCR como bactérias do gênero Brucella. Foi confirmada a detecção de Brucella spp. nos queijos comercializados em mercado ou praça pública $(3,33 \%)$, padaria $(3,33 \%)$ e mercadinho (13,33\%). Brucella spp. foi detectada em queijos artesanais comercializados em diferentes pontos da cidade de Parnaíba. Diretrizes para o estabelecimento de boas práticas para produção de queijos artesanais devem ser determinadas pelas autoridades competentes. No entanto, para melhor controle da brucelose humana é necessário o controle ou erradicação da brucelose nos rebanhos bovinos.
\end{abstract}

Palavras-chave: microbiologia; segurança alimentar; produtos lácteos. 


\section{Introduction}

Brucellosis is a zoonosis caused by Brucella spp. and is transmitted to a person by intake of unpasteurized milk or other dairy products from infected cows or by contact with contaminated secretions (Metin et al., 2015).

Of the dairy products that are derived from milk, cheese is indicated as a source of foodborne microorganisms, particularly artisan fresh cheeses since they are produced, in the majority of cases, from raw milk without following the correct processes. Contamination by pathogens in these products is detrimental for the industry due to economic losses and public health factors, as well as due to the responsibility of transmitting foodborne diseases (Feitosa et al., 2003).

The problems that have been observed in manufacturing cheese curd are associated with the lack of good quality criteria of feedstock and to the lack of adequate processing techniques. This means that low-quality products are distributed in markets that do not have standardized physical and chemical parameters and are therefore dangerous to consumer health because they do not offer microbiological safety standards (Santana et al., 2008; Freitas Filho et al., 2009; Lima et al., 2014).

Forward contamination of food by Brucella spp. can increase the risk to consumers and challenges the public health system due to the complexity of the food chain and the wide market of food of animal origin (Falenski et al., 2011). In a study that was performed in Brazilian airports with dairy products that were transported clandestinely in passenger's luggage from other countries, it was possible to detect the presence of Brucella spp. in $42.1 \%$ from the samples analyzed (70/166) where cheeses were the products with greater number of positive results being $51.2 \%$ of the samples collected (Melo et al., 2014).

Considering that the majority of ingredients for curd cheese is obtained from raw milk and the fact that it has a high humidity content, it is therefore susceptible to bacterial contamination and liable to transmit the brucellosis agent to humans. The aim of this study was to detect of Brucella spp. in artisan curd cheeses commercialized in Parnaíba city, Piauí state, Brazil.

\section{Material and Methods}

A survey of marketing points of artisan curd cheeses was performed in Parnaíba city, Piauí state,
Brazil. Sixty-five marketing points for this product were identified in this city, and among them were samples from thirty randomly collected points: market or public square $(n=4)$, supermarket $(n=2)$, bakery $(n=6)$ and small market $(n=18)$.

During the period from November 2011 to January 2012, $500 \mathrm{~g}$ of cheese were purchased from the marketing points (the products had no indication they had been inspected by any Brazilian institution involved in food safety, such as labeling and appropriate packaging) and were then divided into two samples of $250 \mathrm{~g}$ each. The samples were packed in isothermal boxes containing recyclable ice and sent to the laboratory for processing.

In the laboratory, $25 \mathrm{~g}$ aliquots of the samples were suspended in 100-mL of Brucella broth (HIMEDIA) and were homogenized by using the Stomacher MC 1204 (®ITR) for 60 seconds; after this process, $10 \mu \mathrm{L}$ aliquots of this suspension were sown, in duplicate, in Thayer Martin agar plates (HIMEDIA) that were supplemented with $10 \%$ defibrinated sheep blood and VCNT antimicrobials (HIMEDIA). After inoculation, the plates were placed in anaerobic jars and incubated at $37^{\circ} \mathrm{C}$ for 14 days in microaerophilic conditions. The suspect morphological colonies were identified by Gram stain and were stored at $-80^{\circ} \mathrm{C}$ in polyethylene tubes containing ultrapure water for further confirmation of their genus by polymerase chain reaction (PCR).

To perform the PCR, suspect colonies from the microbiologic analysis were defrosted and 200 $\mu \mathrm{L}$ aliquots were submitted to DNA extraction while utilizing the protocol. The chosen primers were those that have the target region 16S-23S of rRNA for Brucella spp.: ITS66: ACATAGATCGCAGGCCAGTCA and ITS279: Invitrogen ${ }^{\circledR}$ mini-kit for Gram-negative bacteria, according to the manufacturer's AGATACCGACGCAAACGCTAC. For the PCR reaction, a mix with ultrapure water was utilized as the negative control and DNA of the Brucella ovis strain (Reo 198), courtesy of the Veterinary Research Institute Desidério Finamor, was used as the positive control.

The PCR was performed by implementing the method described by Alves et al. (2010). After the initial denaturation at $95^{\circ} \mathrm{C}$ for 2 minutes, the PCR profile was created as follows: 30 seconds (s) of the denaturation mold at $95^{\circ} \mathrm{C}, 30 \mathrm{~s}$ of pairing at $62^{\circ} \mathrm{C}$, and 30 s of primer extension at $72^{\circ} \mathrm{C}$, for a 
total of 40 cycles with a final extension at $72^{\circ} \mathrm{C}$ for 5 minutes. The products of the PCR were analyzed by using $2 \%$ agarose gel electrophoresis (w/v) in a horizontal tank while running the buffer TAE $1 \mathrm{x}$, colored with blue green, and with a standard molecular weight of $100 \mathrm{bp}$. The DNA bands were visualized under UV light and were compared with the standard molecular weight, which was considered to be positive when there was a molecular weight of $214 \mathrm{bp}$.

\section{Results and Discussion}

From the 30 samples of cheeses that were microbiologically analyzed, six (20\%) were confirmed by PCR as bacteria from the Brucella genus. The detection of Brucella spp. was confirmed in cheeses commercialized in the market or public square $(3.33 \%)$, bakery $(3.33 \%)$ and small market (13.33\%) of Parnaíba city, Piauí state, Brazil.

Similar studies have already been conducted in other parts of the world with cheeses produced from the milk of cows, sheep, and goats with characteristics similar to that of curd cheese, and the presence of Brucella spp., B. abortus, and B. melitensis was detected with frequencies varying from $2.2 \%$ to $14.2 \%$ (Kasimoglu, 2002; Akbarmehr, 2011).

The lack of information regarding the vaccine status of the animals that provided the raw material to the production of artisanal cheese, and the ribosomal region amplified by the primers did not allow to differentiate between the vaccine strain (B19) and field strains.

An investigation carried out by Pacheco et al. (2012), detected intermittent excretions of $B$. abortus B19 DNA in the milk of cows up to 9 years old from herds with brucellosis-free certification and immunized with B19 vaccine.

Regardless of the origin of the isolates obtained by the present study, the microbiological viability of the samples after cultivation indicates a significant public health risk, since the consumption of raw milk and / or its nonpasteurized derivatives is considered as the main route of infection of humans by Brucella (Paula et al., 2015).

Several studies were performed to detect Brucella spp. in artisan cheese through isolation of the agent, but obtained negative results (Nascimento et al., 2002; Miyashiro et al., 2007; Zaffari et al., 2007, Kobayashi et al., 2017). The difference among the obtained results can be related to the culture medium that was employed for the isolation of Brucella spp. in products of animal origin. It is highlighted that in this study, Thayer Martin agar was utilized while adding antimicrobials, which may have positively influenced the isolation rate of the agent. The main problem when it comes to isolating Brucella spp. in products of animal origin is contamination by other microorganisms. The presence of competitor microbiota makes it difficult to isolate Brucella spp. in animal products (Zaffari et al., 2007). Thus, culture medium was added with antimicrobials to facilitate pathogen isolation. According to Vicente et al. (2014), the use of appropriate culture medium for Brucella spp. allows for the precise detection of Brucella spp. at different phases of the production chain.

In relation to marketing points, it is highlighted that it was possible to isolate the agent in $20 \%$ of locations that commercialized artisan cheese. In São Paulo state, Brazil, to evaluate the presence of Brucella spp. by the PCR technique, was analyzed 30 samples of raw milk sold illegally as well as $\mathbf{5 0}$ samples of milk delivered to a dairy industry previously to its pasteurization. Of the 80 samples, ten $(12.5 \%)$ were positive. Among the positive samples, five $(16.6 \%)$ were from illegal traders and other 5 (10\%) were obtained from the dairy industry (Paula et al., 2015). These results are concerning from a hygienic-sanitary and public health point of view due to the fact that Brucella spp. can be detected independent of the type of establishment where raw milk or artisanal cheese are commercialized.

It is known that the risk of infection by this agent is highly correlated with the intake of raw milk and dairy products (Kara and Akkaya, 2015). The general population often does not know about brucellosis and does not worry about the conservation, origin, and microbiologic quality of the food. In Nigeria, Adesokan et al. (2013) concluded that infection by Brucella spp. can be facilitated by the lack of knowledge of dairy farmers and traders with regards to the danger of consuming unpasteurized dairy products.

One of the main ways to decrease the risk to the general population is through the implementation of a brucellosis health education program, directed by official defense and public health organizations that aims to alert the general population to the risk of consuming cheese and milk from unknown origins without the correct thermal treatment, since pasteurization can destroy 
this bacterium. Milk pasteurization is an essential practice to preserve the health of consumers and to guarantee the quality of food products; however, the clandestine sale of fresh milk is common in several states of Brazil, despite the mandatory pasteurization rules (Paula et al., 2015).

\section{Conclusion}

The presence of Brucella spp. detected in artisan curd cheeses, which is concerning from a public health perspective because the intake of dairy products is one of the main ways that people can become infected with this microorganism. Guidelines for the establishment of good practices for the production of artisanal cheese should be determined by the competent authorities. However, for the better control of human brucellosis it is necessary to control or eradicate bovine brucellosis in the herds.

\section{Conflict of Interest}

The authors declare no conflict of interest.

\section{References}

Adesokan, H.K.; Alabi, P.I.; Stack, J.A.; Cadmus, S.I.B. Knowledge and practices related to bovine brucellosis transmission amongst livestock workers in Yewa, south-western Nigeria. Journal of the South African Veterinary Association, 84(1): 1-5, 2013.

Akbarmehr, J. The prevalence of Brucella abortus and Brucella melitensis in local cheese produced in Sarab city, Iran and its public health implication. African Journal of Microbiology Research, 5(12): 1500-1503, 2011.

Alves, C.J.; Figueiredo, S.M.; Azevedo, S.S.; Clementino, I.J.; Keid, L.B.; Vasconcellos, S.A.; Batista, C.S.A.; Rocha, V.C.M.; Higino, S.S. Detection of Brucella ovis in ovine from Paraíba State, in the Northeast region of Brazil. Brazilian Journal of Microbiology, 41(2): 365-367, 2010.

Falenski, A.B.A.; Mayer-Scholl, A.; Filter, M.; Göllner, C.; Appel, B.; Nöckler, K. Survival of Brucella spp. in mineral water, milk and yogurt. International Journal of Food Microbiology, 145(1): 326-330, 2011.

Feitosa, T.; Borges, M.F.; Nassu, R.T.; Azevedo, E.H.F.; Muniz, C.R. Salmonella sp., Listeria sp. and hygienic sanitary indicator microorganisms in cheeses from Rio Grande do Norte State. Ciência e Tecnologia de Alimentos, 23(supl.0): 162-165, 2003.

Freitas Filho, J.R.; Souza Filho, J.S.; Oliveira, H.B.; Angelo, J.H.B.; Bezerra, J.D.C. Avaliação da qualidade do queijo "coalho" artesanal fabricado em Jucati - PE. Revista Eletrônica de Extensão, 6(8): 35-39, 2009.

Kara, R.; Akkaya, L. Behavior of Brucella abortus and Brucella melitensis in afyon tulum cheese. Journal of Food Safety, 35(1): 13-18, 2015.

Kasimoglu, A. Determination of Brucella spp. in raw milk and Turkish white cheese in Kirikkale. Deustsche Tierärztliche Wochenschrift (DTW), 109(7): 324-326, 2002.

Kobayashi, P.F.; Carvalho, A.F.; Fredrigo, R.C.; Costa, A.M.; Piatti, R.M.; Pinheiro, E.S. Detection of Brucella spp., Campylobacter spp. and Listeria monocytogenes in raw milk and cheese of uninspected production in the metropolitan area of São Paulo. Semina: Ciências Agrárias, 38(4): 1897-1904, 2017.

Lima, J.R.; Locatelli, G.O.; Finkler, L.; LunaFinkler, L.C. Incorporação de Lactobacillus casei microencapsulado em queijo tipo coalho. Revista Ciência \& Saúde, 7(1): 2734, 2014.

Melo, C.B.; Sá, M.E.P.; Souza, A.R.; Oliveira, A.M.; Mota, P.M.P.C.; Campani, P.R.; Luna, J.O.; Pinto, S.C.; Schwingel, F.F.; Mcmanus, C.; Seixas, L. Bacteria in dairy products in baggage of incoming travelers, Brazil. Emerging Infectious Diseases, 20(11): 19331935, 2014.

Metin, O.; Teke, A.T.; Aydin, Z.G.G.; Kaman, A.; Oz, F.N.; Bayhan, G.I.; Tanir, G. A case of brucellosis mimicking Crimean-Congo hemorrhagic fever. Journal of Infection and Public Health, 8(3): 302-304, 2015.

Miyashiro, S.; Scarcelli, E.; Piatti, R.M.; Campos, F.R.; Vialta, A.; Keid, L.B.; Dias, R.A.; Genovez, M.E. Detection of Brucella abortus DNA in illegal cheese from São Paulo and Minas Gerais and differentiation of B19 vaccinal strain by means of the polymerase chain reaction (PCR). Brazilian Journal of Microbiology, 38(1): 17-22, 2007.

Nascimento, M.G.F.; Cunha, C.P.; Jesus, V.L.T.; Lignon, G.B.; Nascimento, E.R. Levantamento de Brucella abortus em queijos minas frescal comercializados no estado do Rio de Janeiro. Revista Higiene Alimentar, 16(101): 63-66, 2002. 
Pacheco, W.A.; Genovez, M.E.; Pozzi, C.R.; Silva, L.M.P.; Azevedo, S.S.; Did, C.C.; Piatti, R.M.; Pinheiro, E.S.; Castro, V.; Miyashiro, S.; Gambarini, M.L. Excretion of Brucella abortus vaccine B19 strain during a reproductive cycle in dairy cows. Brazilian Journal of Microbiology, 43(2): 594-601, 2012.

Paula, C.L.; Mioni, M.S.R.; Appolinário, C.M.; Katayama, E.R.; Allendorf, S.D.; Megid, J. Detection of Brucella spp. in unpasteurized cow milk by polymerase chain reaction (PCR). Arquivos do Instituto Biológico, 82: $1-5,2015$.

Santana, R.F.; Santos, D.M.; Martinez, A.C.C.; Lima, A.S. Microbial quality of "coalho" cheese commercialized in Aracaju, SE.
Arquivo Brasileiro de Medicina Veterinária e Zootecnia, 60(6): 1517-1522, 2008.

Vicente, A.F.; Antunes, J.M.A.P.; Lara, G.H.B.; Mioni, M.S.R.; Allendorf, S.D.; Peres, M.G.; Appolinário, C.; Listoni, M.F.; Ribeiro, J.P.G.; Megid, J. Evaluation of three formulations of culture media for isolation of Brucella spp. regarding their ability to inhibit the growth of contaminating organisms. BioMed Research International, 2014:(Article ID 702072), 3 pages, 2014.

Zaffari, C.B.; Mello, J.F.; Costa, M. Bacteriological quality of homemade cheeses commercialized in roads of the northern coast of Rio Grande do Sul, Brazil. Ciência Rural, 37(3): 862-867, 2007. 